\title{
Neutral and Basic Amino Acid Transport Protein rBAT
}

National Cancer Institute

\section{Source}

National Cancer Institute. Neutral and Basic Amino Acid Transport Protein rBAT. NCI

Thesaurus. Code 194690.

Neutral and basic amino acid transport protein rBAT (685 aa, $79 \mathrm{kDa}$ ) is encoded by the human SLC3A1 gene. This protein is involved in the mediation of amino acid transport. 